\title{
A CRITIQUE OF THE NEW ATHEISM IN LIGHT OF JOHN PAUL II'S FIDES ET RATIO
}

\author{
Edmon D. Marquez \\ Philippine Normal University-South Luzon, Philippines
}

\begin{abstract}
The present paper seeks to demonstrate John Paul II's encyclical Fides et Ratio as a possible discourse in the polemics of the New Atheism. The New Atheism is a term given to the anti-religion movement of Richard Dawkins, Sam Harris, Christopher Hitchens, and Daniel Dennett. I argue that far from being critical in their reflections of religion, the New Atheists prefer to settle for a version of religious faith categorized as "fideism" or commonly known as "faith alone" theology. What is outstanding is the regularity with which the New Atheists seem to show themselves as mirror images of fideism in that they express the reverse side of it known as rationalism, that is, that any rational enterprise such as the sciences has self-sufficiency of thought without any room for faith or divine revelation. If one examines the argument of the New Atheists closely in the context of Fides et Ratio, one can sense a "literalistic" concept of God, which is hardly the way classical theologians conceived of God. This, in turn, leads to misconceptions of God that are argued away with the same arguments used by followers of fideism to support the existence of God. Hence, both betray structural parallelism in which they feed off one another to fan their arguments. In this paper, I argue that the encyclical Fides et Ratio breaks away from these closed and mitigated conceptions of God and the world and offers a balance between science and religion and between faith and reason. As the encyclical states, "faith and reason are like two wings on which the human spirit rises to the contemplation of truth." Finally, this paper shows that the search for truth, which is ultimately the search for God, is only made possible if both reason and faith work hand in hand.
\end{abstract}

\section{INTRODUCTION}

In the past two decades, academics and the popular press had witnessed a resurgence of atheism under the so-called New Atheism. Anyone who peruses famous bookshops finds book titles such as The God Delusion by Richard Dawkins (2006), The End of Faith by Sam Harris (2004), Why God is Not Great: How Religion Poisons Everything by Christopher Hitchens (2007) and Breaking the Spell by Daniel Dennett (1995). When one begins to read and examine the claims of these fellows, what one 
finds in their writings is their shared points of attacks against religion as the cause of suffering and evil in the world. According to them, to rid the world of this evil, science must take the place of religion. In their understanding, science is the only means of achieving the truth. This belief is called "scientism," and it is the belief that the New Atheists seem to embrace as their worldview. There is, however, a select group known as the religious literalists who are willing to challenge the New Atheism. Like their opponents, they are not unwilling to claim that the sole possession of truth is possible, but only this time, it is religion that possesses the epistemic authority. They believe that this authority is found in the Bible, where the word of God, in their understanding, was dictated to the authors' word by word. Further, they contend that a major source of evil is Darwinian evolution because, for them, it contradicts the Genesis account of creation that is found in the Bible. What is striking is the frequency with which the New Atheists reveal themselves as mirrored images of religious literalism. On the one hand, scientism or "exaggerated rationalism" takes a positivistic mentality that rejects any appeal to metaphysics, and on the other hand, religious literalism's deep mistrust regarding reason itself. This radical separation between reason and faith, as the encyclical Fides et Ratio (Henceforth FR, 1998, sec. 46) highlights, was the result of the rise of science and scientific research in the late Medieval and on to the Modern period.

\section{"MAN HAS COME OF AGE"}

Before the Modern period between the $16^{\text {th }}$ and $18^{\text {th }}$ centuries, Aristotelean scholasticism - the fusion of Greek philosophy and Christian theology-dominated the Western world. This system of thought was the curriculum of the universities and schools of Europe. During this period, the thinkers believed that all things strive for God's created order and life's purpose constituted in following this God-given order in nature. This period, commonly known as the Medieval period, saw the rise of Christian philosophy where reason and faith complemented each other and where the world is seen as God-centered or theocentric. In this worldview, God created the universe and governed it through the natural law discoverable by reason. As Jove Jim Aguas $(2019,240)$ pointed out, all aspects of life in this historical period were seen in the context of the divine, that is, the "end of human life is the eternal salvation in the next world" made possible by a spiritual reality - God.

It was Francis Bacon (1561-1626) who first criticized that the human mind is the cause of many errors and that nature, not the errant mind, must determine the truth and falsity of our beliefs. Bacon emphasizes the experimental sciences that use inductive reasoning over the Aristotelean logic of deduction that was usually derived not from the experience of the world but from universal a priori principles. It was in the area of astronomy that the challenge of the old system of thought began. Among the challenges to Aristotelean cosmology was that of Nicolaus Copernicus (14731543) and Johannes Kepler (1571-1630), who saw the universe through the lens of mathematics and geometry. They both created a more "harmonious" view of the heavens by placing the sun at the center of the system. It was Kepler who believed that the laws of planetary motion disclosed God's mathematical order in the universe. Galileo Galilei (1564-1642), like his predecessor, Kepler, argued that it was 
the observation of mathematical proofs as the means to know God's creation. They were both convinced that they were observing, for the very first time, God's actual work.

Isaac Newton (1643-1727) also played a significant role in the intellectual and scientific revolutions of the 17th century. Following in the footsteps of Francis Bacon's mathematics, Newton formulated the law of gravity, laying the foundation of modern physics. His significant accomplishment was the publication of his Philosophiae Naturalis Principia Mathematica. The publication of Principia demonstrated the Copernican hypothesis as proposed by Kepler. Newton has conceived the world as ordered and coherent, and the way to understand it is through mathematics. More importantly, Newton believed that the natural philosophy could prove the existence of God from the order and contingency of the world. It was the fusion of mathematics and natural theology.

In philosophy, it was Rene Descartes (1596-1650) who freed the discipline from the old system of thought of Aristotle and demonstrated that the physical world was a matter in motion according to the laws of mechanics and that these laws reflect God's creative activity. It was Descartes who first challenged scholasticism in the most fundamental way by arguing that God is a "distinct and clear idea" in the mind. He was convinced that his cogito ergo sum proves the existence of God. According to him, doubt reveals a sense of imperfection. Nevertheless, Descartes $(1997,34)$ believes that imperfection presupposes perfection for how finite beings can conceive the idea of perfection unless it had already been placed there by "nature...that is to say, to put it in a word, which was God."'1

Thus, the old hierarchical view of the world in the Medieval period was replaced by a mechanistic conception of the universe. The world is no longer governed by a divine will or purpose, but rather it is regulated by physics or the laws of mechanics. The world is no longer seen as a teleological world or a world whose end is the salvation in the next world, but that it is meant to be exploited and used to satisfy the needs of human beings. God is no longer seen as the foundation of truth and reality, but experience and reason alone became the basis of understanding reality. Hence, in the Modern period, "man has come of age" and brought about radical and tremendous changes from social to political thoughts. In addition, religion saw a radical change, particularly in the wake of the Thirty Years War between Protestants and Roman Catholics after the Protestant Reformation. It no longer saw the authoritative texts of Aristotle and the Catholic church as the sole arbiter and interpreter of truth. Rather, after the Protestant Reformation, religion put an emphasis on individual faith.

\section{MECHANICAL PHILOSOPHY}

Thus, a new conception of the natural world and its functioning was developed; it was called the mechanical philosophy. It conceived of the world as a great machine functioning mechanically; matter, its shape, and its motion explained natural phenomena. This worldview replaced the old Aristotelean philosophical system. The notion of machina mundi or world machine highly contributed to theology and religion in general. Miracles and even scientific concepts and theories such as atomism were 
all thought to be created and put "into motion" by God. Moreover, if the world is seen as machinery or device, then it necessitates the existence of a divine maker or creator. This notion of God, however, was unlike the Judeo-Christian God, who is loving and personal; rather, this kind of God that was suggested was an "absentee God." In other words, this God is a non-personal and distant God whose concern is primarily the maintenance of the cosmos.

The mechanical philosophy of the Modern period also gave way to naturalism or materialism - the belief that matter is all there is. In turn, materialism led to atheism, which was a new concern in the 17 th century. Responses to mechanical philosophy and its potential toward materialism were proposed. Some thinkers argued that brute matter and motion were simply insufficient. Instead, as David C. Lindberg et al. (1896, 3) argued, these modern religious adherents posited non-sentient, non-corporeal entities to guide natural processes. Robert Boyle (1627-1691), another modern thinker who viewed the role of the natural philosopher as a "priest of nature," rejected this notion believing that such intermediaries are unnecessary. Instead, as Lawrence M. Principe (1998, 190-212) observes, Boyle believed that the activity of God was necessary to continue and uphold the course of nature because brute nature cannot, of themselves, obey laws as others have suggested.

Another characteristic of the science-religion landscape of the 17 th century was the conviction that scientific discoveries would provide the best support for religious belief. Lectures such as the Boyle Lectures were given to combat the rising trend of atheism in the late 16th century. Their series of lectures were funded by scientists who were also deeply religious. Thus, religion was not fully dismissed, or at least the notion of a divine creator who governs the world. Religion, after all, was still part of modernity's worldview or thinking. However, the kind of deity that the modern thinkers conceived of were quite different from the Medieval understanding of God found in Aristotle's metaphysics and the Bible. Their scientific discoveries and mathematical exploration of the universe made them think differently of God. They were genuinely convinced, as James Voelkel $(1999,20)$ writes in Johannes Kepler and the New Astronomy, that they were "following the footprints of God in the universe."

Sir Isaac Newton (1642-1727), for instance, on accounting for all the movement of celestial bodies, argued that it was not mathematics but gravity, which explains all other phenomena. However, since gravity could not explain how the universe came about, Newton had to find its original cause in God. Thus, the complexity that Newton and others were discovering in the universe in the early 17th century, as Karen Armstrong (2010, 196-197) suggested in The Case for God, persuaded them that God must be an "intelligent designer," the first and sovereign being, and the universe as an intricate well-oiled machine set in motion by this all-powerful God. What follows, then, is that if God dwelled in this mechanistic universe, as modern scientists have thought, then religion should be as experimental as any other hypothesis; mathematics and physics would do the job more effectively than theology.

However, the argument of these modern thinkers is problematic because it is an appeal to ignorance in that it creates an ultimately unsuitable "God of the gaps." The phrase refers to an image of a deity that invokes its direct intercession to explain otherwise inexplicable phenomena or situations, that is, to "close the gaps" in 
otherwise naturalistic explanations. Such gaps tend to close with the advance of scientific knowledge, thus putting religion in the position of constant retreat. This is one misunderstanding that religion always retreats before science, and though it is possible that some gaps cannot be closed, it is historically evident that there are few in comparison to the many proposed since the 17th century. The use of knowledge of the natural world to support religious belief developed extensively in the 18 th and $19^{\text {th }}$ centuries; it became known as natural theology.

\section{Arguments from Design}

The drawing of inferences and proofs about God from the natural world has come to be known as natural theology. Although limited theological readings of the "book of nature" have been carried out since antiquity, developed natural theology arose only in the 17th and 18th centuries. Natural theology is a search for an adequate cause for the universe. It emphasizes two characteristics of the universe in that search: the element of recognizable design and recognizable intention. Natural theology is widely appreciated and has been articulated at varying levels of sophistication, but it was most clearly set out by William Paley. ${ }^{2}$ The argument is plausibly extrapolated from the sense of wonder people commonly feel when contemplating natural phenomena - the sorts of things we collect in museums or look at through telescopes and marvel at.

Paley's basic argument starts with the notion that we have the ability to recognize design when we see it, as exemplified by what we would infer if we found a clock among the general detritus on the ground, as opposed to what we would infer if we found a rock there. Paley enumerates and describes a vast array of natural phenomena that he held to be more like clocks than rocks, such as human noses, thumbs, and eyes. He argued that just as we are compelled to infer the existence of an adequate clockmaker from the occurrence of clocks, we are compelled to infer the existence of an adequate eye maker from the occurrence of the eyes. While an adequate clock needs only to be finitely clever and powerful, an adequate maker of eyes must infinitely be wise and powerful.

The argument from design by advocates of natural theology was prone to criticism; upon analysis, it turned out to be weak, ambiguous, and-from the point of view of Christianity-dangerous. Natural theological arguments can result in many kinds of God. A watch may imply a master watchmaker, but it can also imply a company of watchmakers suggesting a polytheistic concept of divinity. The God of natural theology is far from the Christian God - without moral force, unique eternity, personal concern, or other attributes. The basis on which the design argument rests is that God is like a human being. This is a dangerous anthropomorphism. But despite various criticisms, the argument from design is still popular among low-end theologians. An example of this is a recent redevelopment of the argument that has appeared in the United States: intelligent design (Henceforth ID).

ID holds two basic tenets: intelligent causes have a crucial role in the origin and design of the universe and of life and its diversity, and design is empirically detectable in nature. In so far as ID is akin to natural theology, deploying the argument from 
design is susceptible to all critiques, weaknesses, and problems of natural theology. However, some ID proponents differentiate their position from natural theology by claiming that ID is not about proving the existence of a designer but, rather, exploring what the assumption of a designer can explain. One of the arguments for ID is the concept that there are structures in nature, especially among living things that are "irreducibly complex."3 This means that the kind of complexity displayed by these structures cannot be explained by a purely naturalistic development. A classic example is the structure of the eye from the late 19th century. A system, like the human eye, is irreducibly complex if it has multiple parts that otherwise cannot work together if one or two of its parts do not function. For instance, if we take away the retina or the lens, the eye will not function correctly. The primary argument here is that there is no way each of the parts of the mechanism, in this case, the eye, independently evolved because there is no fitness or benefit that it can get from having evolved on its own. It is only when the individual parts are functionally working together as a unit that it can get some benefit from the structure. And so, it is impossible to explain how these structures came about from a purely naturalistic selection. ${ }^{4}$

And so, ID has come to be usually presented in competition with science, particularly evolutionary biology. ID advocates accept that natural selection is beneficial in explaining the development of life. They accept many of the natural processes that evolutionary biology posts. ID theories, however, do not think that these complex developmental stages of life on earth are enough to explain the development of life. Thus, they add an "extra" feature - the interaction or intervention of an intelligent designer in the developmental stages of life on earth. However, the problem in this line of thinking is that if the theory may be considered science at all, it must be able to come up with scientific predictions, which it fails to do so. Evolutionary biology is science precisely because it is "formalizable" in that it can derive the right predictions about evolutionary theory for various situations and various biological phenomena. The ID theory cannot do that because it involves a variable that is unable to answer as to when and to what extent it intervenes in the development of life on earth. At best, the ID theorists settle on the idea that we do not have yet any formal system for understanding the behavior of an intelligent designer.

\section{Scientific Naturalism}

With the rise of the sciences in the Modern period, it gave way to another trend which has tremendous ramification until the 19th and early 20th centuries, and that is, a positivistic mentality that rejects any contents of faith as well as metaphysics as the encyclical Fides et Ratio underscores (1998, sec. 45). This type of thinking is commonly known today as scientific naturalism. Although the term naturalism is nuanced in its definition, as David Papineau (1997, 12-15) argues in "Naturalism," it has no precise meaning in contemporary philosophy. But what we are particularly concerned about is scientific naturalism, which is a specific form of naturalism. Denis O. Lamoureux $(2008,38)$ defines scientific naturalism as a conflation of science, secular philosophy, that is, non-religious philosophy and humanist ethics. By humanist ethics, it means an ethical position in which human beings determine morals as well as values 
without any appeal to God. It is worth noting that scientific naturalism does not always maintain that science and its method can give an account of everything. However, it has kept its belief that science has a more reliable source of knowledge compared to that of religion. This is true among the New Atheists. For instance, Dawkins $(2006,85)$ believes that "it may be that humanity will never reach the quietus of complete understanding, but if we do, I venture the confident prediction that it will be science, not religion that brings us there. And if that sounds like scientism, so much the better for scientism."

Philosophers usually categorize naturalism into two different components, the ontological and methodological components. The ontological or metaphysical naturalism investigates the nature and contents of reality and asserts that the natural or physical world available to the senses is all there is. This type of naturalism claims that there is no "transcendent" or supernatural realm or entity of any kind. To put it explicitly, the central claim of ontological naturalism is the belief that there is nothing more than the mental, biological, and social realms than an arrangement of physical entities. By contrast, the methodological or epistemological component concerns itself with ways of investigating reality. It primarily uses the scientific method. In general, this component of naturalism concerns itself only about the natural scientific method and not about the philosophical method. What this means is, as the word methodological suggests, this type of naturalism only focuses on the use of scientific method within science. In other words, other commitments such as religious commitments have no bearings of any kind as natural science requires no commitment to religion. As this line of thought goes, one can practice natural science in just the same way as someone who does not have any religious affiliation yet remain a religious adherent when it comes to religious beliefs and questions. By and large, the New Atheists seem to gravitate towards the unrestricted and ontological scientific naturalism.

\section{WARFARE THESIS}

Natural theology and ID theory led to a fundamentalist and literalist attitude of some Christian denominations, while scientific naturalism developed into its recent form known as scientism advocated by the New Atheists. In "One Dimensional Rage: The Social Epistemology of the New Atheism and Fundamentalism," William A. Stahl (2010, 97-108) argues that both camps see their positions as good and their opponent's evil. However, as others have pointed out, such as Jeffrey W. Robins et al. in "Beating God to Death: Radical Theology and the New Atheism," beneath their superficial warfare lies a resemblance in that they both share a common metaphysical worldview or belief. John Haught (2008, 30), for instance, argued that both the New Atheists and religious literalists share the belief that there is nothing underneath the "text" they are reading - nature in the case of the scientistic and naturalistic philosophy of the New Atheists and the Bible in the case of the religious literalists. The New Atheists presupposes that the universe is self-sufficient, and that science provides the ultimate explanation of the universe, while religious literalists assume that the whole of reality can be understood and explained in the literal reading of the Bible. ${ }^{5}$ Hence, it is safe to say that the New Atheists' notion of God and how theology works are the same as those of religious literalists. They treat the Bible as a literal and historical book and a 
source, not just of religious information, but also of scientific knowledge. The only difference between them is that the former considers the Bible as an unreliable source of scientific knowledge, while the latter does not.

\section{Creationism and Darwinian Evolution}

In 1859, Charles Darwin [1809-1882] $(1997,1981)$ published his Origin of Species; this was followed in 1871 by The Descent of Man. Three important features of Darwin's theory of evolutionary principles were common ancestry, speciation through variation, and natural selection. Common ancestry holds that all species in existence today originate from a single ancient organism or a very small number of ancient organisms. Species, it follows, come about through the variety of forms, organs, and instincts, these variations though random, are determined by a natural selectionthe mechanism for speciation where useful variations promote survival and favor.

The ideas of Darwin came at a time of intellectual crisis. Europe was in the wake of modernity departing from the old Medieval world. However, the more obvious result of Darwin's theory of evolution is its various impacts on theology. There was an impact on biblical authority in terms of the historicity of the book of Genesis. The ID theory was undermined by the notion of random variations and natural selections. Old theological problems resurfaced, such as God's activity in the world. If species can develop naturally without the need for special creation, then God is no longer needed or relevant. Moreover, a merciful and benevolent God was replaced by nature run by violent, brutal natural selection. Moreover, with the ID theory undermined by random variation, atheism was again an issue.

Many such as the Princeton Presbyterian theologian Charles Hodge [17971878] (1940, vol.2) equated Darwinism with atheism. Other religious literalists, along with Hodge, embraced creation science, where it thinks of the world being created around 4,000 to 5,000 years ago, and that life on earth was created as it is now. And though the evolutionary theory is not a theory of the origin of life on earth but only how life came about, it is the concept of natural selection that receives much criticism from young-earth creationists because of its anti-theological implications. On the other hand, ID theory, like the evolutionary theory, accepts that the earth and all living things in it underwent a long process of developmental stages. In other words, the ID theory does not accept the young-earth hypothesis. However, ID theory is not compatible with evolutionary biology, either in that it posts a different kind of mechanism for the development of life on earth. One particular mechanism is the idea of "interaction" with an intelligent designer in the development of life on earth. That makes the ID theory something in between creationism and evolutionary biology. For the most part, it replaced creationism in the discussion of science versus religion, and their disagreement rests upon their two opposing ideas of mechanisms for the development of life.

\section{Atheism: A Specter of a Misconstrued God}

The narrow version of creationism and its literal interpretation of both the book of "nature" and the Bible resulted in a crisis of faith. This crisis, in turn, created atheism. The religious literalists view posted a direct opposition to the modernist 
worldview brought about by science and Darwin's evolutionary theory. Thus, both worldviews seem to appear in perpetual warfare with one another. Darwinian evolution argues that God did not create the world exactly as we know it, but that species had evolved over a long period of adapting to their environment. This undermined the literalists' worldview and quickly responded. They criticized the theory of evolution as relying too much on its scientific explanation. They argue that it disregards the Bible and its account of creation as equally scientific and factual. As Hodge (1950, 33-65) puts it in "What is Darwinism," Christians must unite and "fight for its life against a large class of scientific men."

The New Atheism movement for the past two decades is a necessary result of modernity's natural theology and ID theory and its criticism of the literal reading of the Bible and the scientistic interpretation of nature to prove the existence of God is justifiable and even the proper response. Sam Harris $(2006,20)$, for instance, criticizes the bad science on display in the book of Genesis. And rightly so. How can one possibly make sense of the creation account in which God created the world in six days where all the species came into being roughly at the same time? Or how can one square with the Genesis' naïve mythological cosmology with the work of, say, Galileo or Newton? The debate, then, between the New Atheists and religious literalists ensues from a misguided concept of the Bible and God. Both have neglected that one must be sensitive to what kind of text or genre they deal with within the book of Genesis or the Bible in general. For instance, modernity begins in the late 16th and early 17th centuries. The Bible, however, was compiled as early as the 3rd century. Taken from this context, there is just no way that the Bible is modern science, as religious literalism insists because modern science did not exist yet! So, whatever is going on in the Bible is not what we mean by modern science. Hence, atheism is correct and justified as the reaction to Biblical literalism and natural theology.

\section{FIDES ET RATIO}

For the New Atheists, what represents religion is religious fundamentalism and literalism. For them, such as Dawkins $(2006,188)$, religion is a kind of "misfiring" in the evolutionary process. Further, the New Atheists do not think that intellectual engagement or discussion will benefit religion, and for religious thinkers who employ reason, according to Harris $(2004,19-21)$, they are no more than the result of the "many hammer blows of modernity that have exposed certain tenets of faith to doubt." These "religious moderates" betray reason and faith altogether. In thinking of fundamentalism as the authentic representation of Christianity, the New Atheists seem unaware of the long tradition and history of the Christian religion. The result of this is that they take religious fundamentalism and religious literalism as the essence of Christianity. They do not realize that these forms of religion are products of a scientistic and modern worldview of the 17th to the 19th centuries. The New Atheists also seem to lack historical perspective and fail to consider that as early as the 2nd and 3rd centuries; early Christians were reading the Bible in a much more complicated and sophisticated manner. 
John Paul II's Fides et Ratio (FR), published in 1998, deals precisely with our issues at hand. The document sketches a useful history of the relationship of faith and reason in theology, where it reaffirms Catholic intellectual traditions such as the relationship of faith and reason, which it calls "two wings on which the human spirit rises to the contemplation of truth" (FR 1998, sec. 1). Without the combination of faith and reason, the human person is incapable of knowing himself, the world, and God (FR 1998, sec. 16). Human beings can apprehend God's existence by reflecting on creation because man is gifted with the ability to reason and think (FR 1998, sec. 19). Ultimately, human beings cannot avoid seeking the truth because they must find the truth to address life's ultimate questions. In fact, man can be defined as "the one who seeks the truth" (FR 1998, sec. 26). It also reminds its readers of the correct biblical interpretations and to "remember that the various hermeneutical approaches have their own philosophical underpinnings, which need to be carefully evaluated before they are applied to the sacred texts" (FR 1998, sec. 55).

\section{Relationship of Faith and Reason}

The encyclical explains the proper interaction between faith and reason, between philosophy and theology. Philosophy is the study of ultimate truth under the natural light of reason, and theology is the study of faith with revelation as its first principles. The purpose of theology is to permit a greater understanding of the faith so that it can be grasped more firmly (FR 1998, sec. 93). Reason, on the other hand, prepares the way to faith. St. Justin Martyr (100 A.D.-165 A.D.) used philosophy as a "preamble" to the faith as the encyclical makes mention of the saint (FR 1998, sec. 38). This means that using philosophical logic, one can show that faith is not contrary to reason but a "steppingstone to the faith." Reason, properly understood, can show that there is a God and can demonstrate God's primary attributes as God's power and divinity. In other words, reason lays the foundation for faith and makes revelation "credible." Reason is thus the common ground between believers and unbelievers.

The encyclical further stresses that faith without reason withers into myth or superstition. Deprived of reason, faith is left with only feelings and experience. It loses its universality (FR 1998, sec. 48). Philosophy fills this lacuna, for it provides a language for theology. Its concepts and patterns of thought permit theology to have a logical structure and to be a true science (FR 1998, sec. 65). For example, while the Real Presence in the Holy Eucharist is to be believed as a matter of faith, theology attempts to make it more understandable in terms of substance, accidents, and transubstantiation, etc. The philosophical language permits theology to speak about God, the personal relations within the Trinity, God's creative activity in the world, the relationship between man and God, and Christ's identity as true God and true man, to take a few examples.

However, just as reason assists faith, the encyclical also explains how faith supports reason and how theology supports philosophy. Human reason is inherently weak and inclined to error, as proven by erroneous philosophies. When deprived of revelation, reason can go off course and miss its destination (FR 1998, sec. 48). Faith also guides reason to discover ways that it would not otherwise have thought it could 
take. It offers truths that might never have been found by reason alone. For instance, the idea of free will and a God who is personal and creator of the cosmos have been essential for the development of metaphysics and the Christian belief on the inviolability of the human person, seen in modern philosophical thoughts (FR 1998, sec. 76). Faith also provides the philosopher the strength to take on difficult questions like the problem of evil and human suffering, the nature of God, and fundamental questions such as "why is there something rather than nothing?" Faith gives him or her the belief that his or her capacity to think will find answers, like a genuine map giving him or her the trust to keep digging. Lastly, faith keeps the philosopher from intellectual pride that would hinder his or her ability to quest for the truth. Faith, supported by love, helps the intellectual understanding of the truth about the human person and his or her real desires.

The encyclical thus strengthens the coherence between faith and reason. "Faith asks that its object be understood with the help of reason, and at the summit of its searching, reason acknowledges that it cannot do without what faith presents" (FR 1998, sec. 42). As the encyclical suggests, because the light of reason and the light of faith both come from God, there can be no conflict between them (FR 1998, sec. 43).

With the rise of extreme rationalism, faith and reason became divorced with terrible consequences. The result is the skepticism that we are now experiencing. Skepticism or nihilism contains no promise of meaning and objective truth (FR 1998, sec. 46). It sees only the practical ends of power and pleasure. Human beings are treated as objects to be used rather than as persons to be respected. This age of nihilism is manifested in contemporary cultures, such as art, music, literature, and pop culture. As a result, the "culture of death" replaces the culture of life. If this continues, as Pope John Paul II (1995, sec. 18) stressed in his 1995 address to the 50th General Assembly of the United Nations, the next millennium will bring a "new era of barbarism rather than a springtime of hope." The encyclical concludes by providing challenges for philosophers and theologians. The document states that philosophy needs to reclaim its "sapiential dimension," that is, it must revive its quest for wisdom and the meaning of life. More than ever, philosophy must go beyond the empirical data and think about spiritual realities such as truth, beauty, and goodness (FR 1998, sec. 83).

\section{Fides Et Ratio as an Antidote to a Domesticated Concept of God}

We have become used to the idea that religion is a set of rules, dogmas, and truth-claims about the world so much so that the question "does God exist?" has become naturalized and domesticated. What the encyclical Fides et Ratio has brought out is that we have reduced the concept of deity with a precise and definite function. In the Modern period, the concept of God was diminished to a scientific God, an intelligent designer, who became the ultimate explanation of the universe. Where science failed, God filled this abyss of unknowability and served as the final explanation or hypothesis in a mechanistic universe. However, when God is no longer the symbol that is meant to point beyond itself to a reality beyond the human sense, atheism becomes a reasonable option for many people. Because sooner or later, science will be able to find a hypothesis about the world that can replace an intelligent designer. This, of course, renders the concept of God superfluous. 
What Fides et Ratio has clearly pointed out is that the literalists' and the New Atheists' concept of God has relied on the idea that God's existence can be proven scientifically. More and more, this "war" between science and religion has pushed and relegated other paths to knowledge and only regarded the scientific method of verification as the sole arbiter of truth. To this effect, modern human beings have thought of God as self-evident, or at least can be proven scientifically. The New Atheism is only a reaction to this misguided concept of God-a specter which literalism and fundamentalism created. Fides et Ratio reminds its readers that faith and religion must be engaged in a manner that goes beyond its literal sense and allow faith and reason to work hand in hand, only through the relaxing of the "scientific mind" and the intellect that one will be exposed to the immense possibility that far stretches beyond the physical universe.

This limit and inadequacy of one's knowledge about God are what apophasis means. It challenges the New Atheism (and us, though indirectly) to think of God beyond the categories of being because God is not a being but, as Paul Tillich (1952, 184) argues, God is "being itself" or the "ground of being." What this means is that God is not identical with the universe as modern science would have us thought of God. Instead, God is the "substantive cause and maker of being." As such, God is the source of everything in the sense that everything that exists depends on God in virtue of their contingent character. To put it another way, God is not a being because God does not belong in the order of created and contingent beings. However, God is not a "superior being" either. Instead, God is outside the categories of being because God is "superior" to and precedes being.

Beyond the polemics of the New Atheism and religious literalism, Fides et Ratio offers a possibility of an answer or a solution. It is one that acknowledges that faith and religion cannot provide scientific answers but provides the ground for scientific discovery. This non-literalist model provides the intellect immense possibility that naturalism cannot succeed in its self-limiting metaphysics. Hence, religion cannot oppose science but supports it as science, like any other human activities such as the arts and politics, that contributes to human flourishing and open the human person to God. Science can tell us anything about the natural world and how it neatly fits together as the laws of physics govern it, but it cannot tell us anything about God. On the other hand, the tasks of faith are to assist us to live with courage and confidence despite life's uncertainties and difficulties. Faith is never meant to provide us with factual and literal information about God, and that whatever knowledge we may have of God, it will always be limited and inadequate.

\section{CONCLUSION}

The interaction between science and religion has been complex over time and are not reducible to the simple blanket description. The warfare thesis depends on the existence of separate "camps" of theologians and scientists; this is a relatively recent division. Both parties involved in the current controversy have adopted it as a model for their own behavior. A closer look at the warfare thesis metaphor appeals to the Manichean mindset of many fundamentalists - both religious and non-religious: the 
duality of faith and reason, theology, and philosophy. Some scientists, crusading for materialism and atheism, support fundamentalist fears and have often forgotten the difference between a professional policy of not invoking supernatural action against everything supernatural. In other words, scientists should avoid making theological or metaphysical claims when they are unqualified to do so. The result of the warfare thesis is the hardening of positions that create division where it need not exist. The perception of this controversy ignores the vast field of cooperation and intelligent conversation by the majority in between. Fundamentalists do not have the right to speak for Christianity; declamatory supporters of scientism do not have the right to speak for science. Both lack a sense of humility before the complexity of the world and man's place in it.

Historically speaking, the movement of ideas back and forth between theological and scientific thought has been more usual. Both have grown up together in Western thought and share several methods and aspirations. Christian theology developed certain methods, perspectives, and cultural environment and provided science institutional support or patronage for studies of the natural world. Likewise, science has provided theology with a truer sense of man's place in the world. Christian theology has proven itself remarkably flexible in its stability to adopt, adapt, and explore new scientific findings. Although clearly false as a philosophical and theological model, the warfare thesis seems supported by current events, particularly involving evolutionary biology. Part of the reason is that science and technology have been regularized by professionalism, granting it greater authority. On the other hand, theological activity has become diffused by decreased ability to professionalize theologians; the result has been lower-level theology and a loss of status and authority. One cause may simply be unfamiliarity with historical theology and current "highend" or philosophically sophisticated theology. Thus, the study of history and philosophy is again a solution.

\section{NOTES}

1. This quotation is taken from a compilation of Rene Descartes' works. See Haldane and Ross $(1997,34)$.

2. See William Paley (1986).

3. This general treatment of intelligent design theory and evolutionary biology is found in Philosophy, Science, and Religion: Religion and Science. See Scharp (2019, lec.4).

4. From an evolutionary biology standpoint, however, evolutionary theory has developed over the last century so that it has been able to explain more phenomena, especially in the realm of biology. Many things that were previously thought to be irreducibly complex it is now able to consider. In the case of complex structures, modern biology thinks that parts can develop and evolve independently as it depends on the environment in which that organism finds itself. In other words, it might be that the parts that came together to form what seems like an irreducibly complex structure have independent functions and have benefits for the organism before all the parts come together in one system of the body. The body uses different structures and parts that were utilized for something different in the past. 
5. For instance, James McCosh argues that theology is a science, and that God works as a natural phenomenon. So, in his reading, theology must make use of the scientific method to discover the will of God. See McCosh $(2009,28)$.

6. See Luibheid (1987).

\section{REFERENCES}

Aguas, Jove Jim S. 2019. The Challenge of Secularization to the Christian Belief in God. In Philosophia: International Journal of Philosophy (20) 2: 238-52. doi.org/10.46992/pijp.20.2. a.6.

Amarasingam, Amarnath. 2010. Religion and the new atheism: A critical appraisal. Leiden: Brill.

Armstrong, Karen. 2010. The case for God. New York: Anchor Books.

Darwin, Charles. 1997. On the origin of species by way of natural selection. London: John Murray Press.

Darwin, Charles. 1981. The descent of man. Princeton. Princeton University Press.

Dawkins, Richard. 2006. The God delusion. London: Bantam Press.

Dennett, Daniel. 2006. Breaking the spell: Religion as a natural phenomenon. New York: Penguin.

Elizabeth S. Haldane, and G. R. T. Ross. 1997. Descartes: Key Philosophical Writings. Hertfordshire: Wordsworth Editions Limited.

Harris, Sam. 2004. The end of faith. New York: W.W. Norton and Company.

Harris, Sam. 2006. Letter to a Christian nation. New York: Knopf

Haught, John F. 2008. God and the new atheism: A critical response to Dawkins, Harris, and Hitchens. Louisville: Westminster John Knox Press.

Hitchens, Christopher. 2007. God is not great: How religion poisons everything. New York: Allen and Unwin.

Hodge, Charles. What is Darwinism?

https://www.ccel.org.//ccel/hodge/darwinism.html. n.d. Accessed: December 28, 2019.

Lamoureux, Denis. 2008. Evolutionary creation: A Christian approach to evolution, Cambridge: The Lutterworth Press

Lindberg, David C., and Ronald L. Numbers. 1986. Beyond war and peace: A reappraisal of the encounter between Christianity and science. Church History, 55 (338).

Luibheid, Colm. 1987. Pseudo-Dionysius: The complete works, New York: Paulist Press.

McCosh, James. 2009. The method of divine government physical and moral. New York: Cambridge University Press.

Paley, William. 1986. Natural theology or evidence of the existence and attributes of the deity. London: Lincoln-Rembrandt Publishing.

Papineau, David. 2015. Naturalism. In Stanford Encyclopedia of Philosophy. Stanford University. https://plato.stanford.edu/entries/naturalism/.

Paul II, John. 1998. Fides et ratio. Vatican City: Liberia Editrice Vaticana.

Paul II, John. 1995. Apostolic journey of His Holiness John Paul II to The United States of America. Vatican City: Liberia Editrice Vaticana. 
Principe, Lawrence. 1998. The aspiring adept. Princeton, NJ: Princeton University Press.

Robbins, Jeffrey W., and Christopher D. Rodkey. 2015. Beating God to death: Radical theology and the new atheism. In Retrieving the radical Tillich: His legacy and contemporary importance. New York: Palgrave Macmillan.

Scharp, Kevin. 2019. Philosophy, Science and Religion: Religion and Science. Coursera. https://www.coursera.org/learn/philosophy-science-religion-3. Accessed: December 30, 2019.

Stahl, William A. 2010. One-dimensional rage: The social epistemology of the new atheism and fundamentalism. In religion and the new atheism: A critical appraisal. Leiden: Brill.

Tillich, Paul. 1967. Systematic theology: Three volumes in one. Chicago: University of Chicago Press.

Voelkel, James R. 1999. Johannes Kepler and the new astronomy. New York: Oxford University Press. 